\title{
THE IMPACT OF THE SOIL ADDITIVES APPLICATION ON THE RAINWATER SURFACE RUNOFF
}

\author{
Katarína Drgoňová', Beáta Novotná2, Jaroslav Antal' \\ 'Department of Biometeorology and Hydrology, Faculty of Horticulture and Landscape Engineering, Slovak \\ University of Agriculture, Hospodárska 7, 94976 Nitra, Slovak Republic, e-mail: kd.drgonov1@gmail.com \\ 2 Department of Water Resources and Environmental Engineering, Faculty of Horticulture and Landscape \\ Engineering, Slovak University of Agriculture, Hospodárska 7, 94976 Nitra, Slovak Republic
}

Received: 2016.08.11

Accepted: 2016.09.26

Published: 2016.11.01

\begin{abstract}
The main aim of this work was the application of the soil additives into soil and the study of their impact on the amount of surface runoff originating from rainwater. Execution of research was carried out on the modified portion of the land at Department of Biometeorology and Hydrology, SUA Slovakia. Land was divided into four experimental plots. Individual treatments consisted of application of perlite, charcoal and water glass into the top layer of the experimental plots. The fourth experimental field was kept as a black fallow (control). To perform the measurements, rainfall simulator was used in six measurement series. We can conclude that the application of perlite is not an adequate treatment for erosion control practices, since its application increased the surface runoff. Increased application dose of additives resulted in the positive effects of the water glass application. Surface runoff for this treatment decreased in average by about $41 \%$ in comparison to control. This positive effect was observed only after the second application of the soil additives.
\end{abstract}

Keywords: water erosion, surface runoff, soil additives, rainfall simulator, rainwater modelling

\section{INTRODUCTION}

The surface soil layer structure has a determinative influence on the surface runoff formation and thereby also on the water erosion. The soil structure considerably influences the water infiltration rate and water capacity of the soil profile [Janeček et al. 1999].

Surface runoff is defined as a part of the rainwater, which after subtraction of the vapour losses by evapotranspiration, infiltration into soil and by retention on the soil surface, flows on the top of the soil. The surface runoff is influenced by:

- climatic factors (atmospheric precipitation, evaporation, wind),

- physical-geographical factors (physical characteristics of the river basin),

- human action [Holý and Váška 1982].
Policy guidelines in the field of erosion control can be expressed by following sentence: „If there is no surface runoff; then there is no erosive transport of soil by water erosion [Antal 2005].

The research problems in the soil and water management are usually connected with the natural conditions such as weather, soil, etc. Any attempt to simulate or model these phenomena meets some problems. Wind, solar radiation, temperature, humidity, vegetation, soil surface are just some of the factors, which are difficult to model and simulate. It is more difficult to extrapolate these measurements to the field conditions and natural rain. The used water amount and simulator construction size, clearly limit the irrigation area size [Janeček et al. 2008]. 
For the purposes of the rainfall-runoff and erosive effects study rainfall simulator may be of good help. It enables the artificial precipitation application, which is a very similar to the natural heavy rains according to the research demand. Kasprzal [Fulajtár and Janský 2001] also confirmed the similarity of the physical characteristics between natural and an artificial rainfall.

Rainfall simulators were developed for the erosion measurements resulting from the natural rainfall. They have been used in the laboratories as well as in the field experiments to study the basic mechanisms of the surface runoff, erosion processes, erosion impact assessment, tillage practice, plants types, soil residues, other soil surfaces and soil management; slope length, steepness, shape, soil characteristics and erodibility [Toy et al. 2002].

Therefore, the simulated rain is considered as a great advantage when the rainfall simulator is applied. The research can be realised without the dependence on the natural rain occurrence. The aim of our contribution was to study the effect of various soil additives on the surface runoff generated from the rainfall simulations. We hypothesized that the individual soil additives will decrease the amount of surface runoff.

\section{MATERIAL AND METHODS}

\section{Site preparation for the experiment implementation}

The experimental site was located on the former permanent pasture at the school campus of the Faculty of Horticulture and Landscape Engineering, Department of Biometeorology and Hydrology, SUA in Nitra in the Zobor suburb. During the pre-establishment of the site, the vegetation cover was chemically removed from the soil surface by herbicide. Since we wanted to apply the soil additives into the soil and catch the originated surface runoff such modification was necessary. The herbicide application was realized twice in two weeks duration. During the second herbicide application, special attention was paid to the sides and edges of the ground to avoid the vegetation and weed spreading on bare soil of the prepared research area. After that soil was aerated, soil surface was levelled and the site was divided into four plots. The plot dimensions were $2.50 \times 2.10 \mathrm{~m}$. The handling space of $0.5 \mathrm{~m}$ was left between the individual plots to avoid the soil compaction. After each measurement, the ground was covered by a plastic foil to be able to perform the measurements next day without the disturbance of the possible natural rain that might occur during night [Drgoňová 2014].

\section{Preparation and application of the soil additives into soil}

Perlite, charcoal and water glass were chosen as the soil additives that should potentially decrease the amount of surface runoff during the simulated rainfall event. For the purposes of the first measurement series $150 \mathrm{~g}$ of perlite, 1400 $\mathrm{g}$ of charcoal and water glass diluted with water in the ratio of $1: 2(650 \mathrm{ml}$ of the water glass : $1300 \mathrm{ml}$ of water) were applied into the soil. The fourth plot was left as a fallow to provide the control measurements. Water glass is a colourless transparent aqueous solution of disodium silicate with a high viscosity and density of about $\rho=1.4$ g. $\mathrm{cm}^{-3}$. After its application on the soil surface by spraying, a white film was created on the top of the soil. We decided to use the charcoal due to its high porosity and the ability to retain water into soil. Our interest was to investigate, whether it is a good absorbent. Before its application into the soil, it was crushed into small dusty particles. Because the perlite is a synthetic mass adapted into aggregates of different size, it was more difficult to work with it.

Prior to the second series of measurements, the additives were applied again with dosage $+200 \mathrm{~g}$ of perlite, $+712 \mathrm{~g}$ of charcoal and at the same amount of water glass $-1300 \mathrm{ml}$ of water glass: $2600 \mathrm{ml}$ of water. After the additives incorporation, the soil surface was aligned [Drgoňová 2014].

\section{Rainfall simulator - characteristics and its utilization in practice}

The simulator allows the erosion to occur also on a small ground area. The rain is simulated by the apparatus on an inclined surface. Raindrops fall through the small capillaries.

When the droplets fall to the soil surface, they cause the soil particle detachment. Water and soil particles are collected into a retention vessel in the direction of slope. Examination of the trapped particulates in the laboratory can determine the soil composition and the soil predisposition to erosion. When comparing the measurement results, 
we can develop the susceptibility of soils to erosion. Water temperature and the land use history belong among the factors influencing this process belong [Regensimulator für Erosionstests 2016]. Rainfall simulator consists of three main parts (Figure 1):

1. Sprinkler with the integrated pressure regulator for the formation of rain,

2. Adjustable pillar for the sprinkler,

3. The aluminium frame that is placed on the soil, preventing lateral overflow of water from the test area into the surrounding ground [Operating instructions 2016].

Table 1. The rainfall simulator technical parameters [Operating instructions 2016]

\begin{tabular}{|l|c|}
\hline \multicolumn{2}{|c|}{ Rainfall simulator } \\
\hline Technical specifications: & $330 \times 330 \mathrm{~mm}$ \\
\hline Sprinkler dimensions & $10 \mathrm{~mm} \pm 1 \mathrm{~mm}$ \\
\hline Length of capillair & $0.6 \mathrm{~mm} \pm 0.08 \mathrm{~mm}$ \\
\hline Diameter of capillair & glass \\
\hline Material of capillair & $18 \mathrm{~mm}$ \\
\hline Magnitude of rain simulation & $3 \mathrm{~min}$ \\
\hline Duration of rain simulation & $6 \mathrm{~mm} / \mathrm{min}^{-}$ \\
\hline Intensity of rain simulation & $5.9 \mathrm{~mm}$ \\
\hline Diameter of drops & $0.106 \mathrm{~g}$ \\
\hline Mass of drops & $4 \mathrm{~J} . \mathrm{m}^{-2} . \mathrm{mm}^{-1}$ \\
\hline Kinetic energy of rain & $0.0625 \mathrm{~m}^{2}$ \\
\hline Surface area of test plot & $\mathrm{max} .40 \%$ \\
\hline Slope of test plot &
\end{tabular}

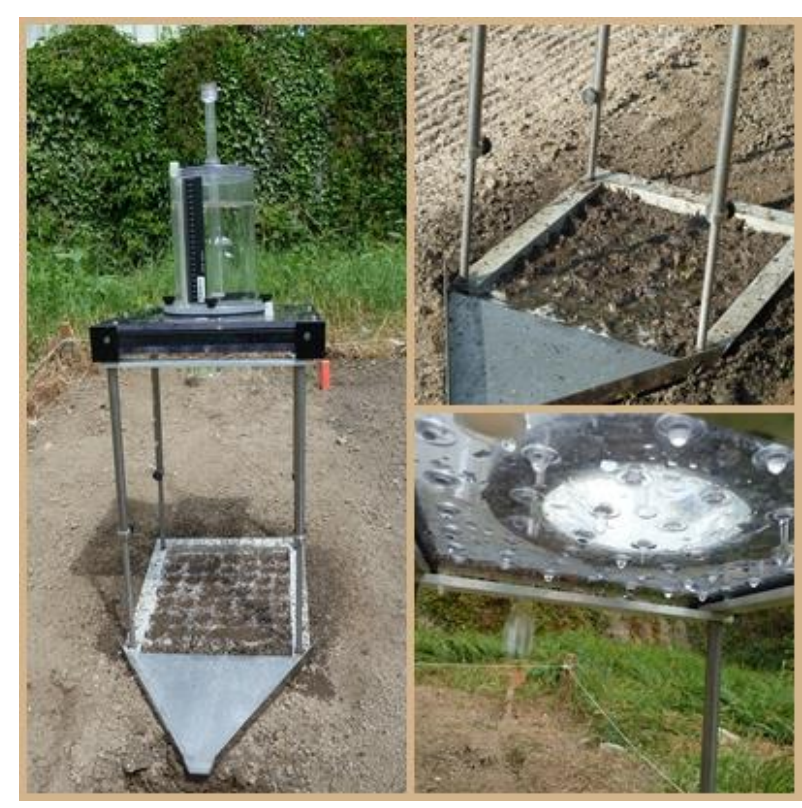

The technical parameters of the rainfall simulator used in the study are present in the Table 1.

\section{RESULTS}

Each measurement for the individual soil additive and control consisted of four partial measurements (repetitions). The outputs of the first measurement were skipped during the result evaluation since it was a "stabilisation measurement" [Drgoňová 2014].

The volume runoff coefficient of the surface runoff $-\varphi_{\text {O.p }}$ was defined according to Antal [2010] by the following formula:

$$
\varphi_{O, p}=\frac{H_{O, p}}{H_{z}}
$$

where: $H_{O, p}$ - amount of surface runoff from the examined rain $[\mathrm{mm}]$,

$\mathrm{H}_{Z}$ - amount of the examined rain [mm].

Value of $35.2 \mathrm{~mm}$ (water that was poured into the rainfall simulator for each of the rain simulation) was appointed for $H_{Z}$. The amount of surface runoff $H_{O, p}$ per measurement [mm] was obtained after measuring the volume of trapped surface runoff by the graduated cylinder in $\mathrm{ml}$ and subsequent conversion to $\mathrm{mm}$. Prior to the surface runoff volume measurement, the suspension was filtered through filter paper to divide the detached soil particles from the trapped surface runoff and thus the water originating from rainfall simulation.

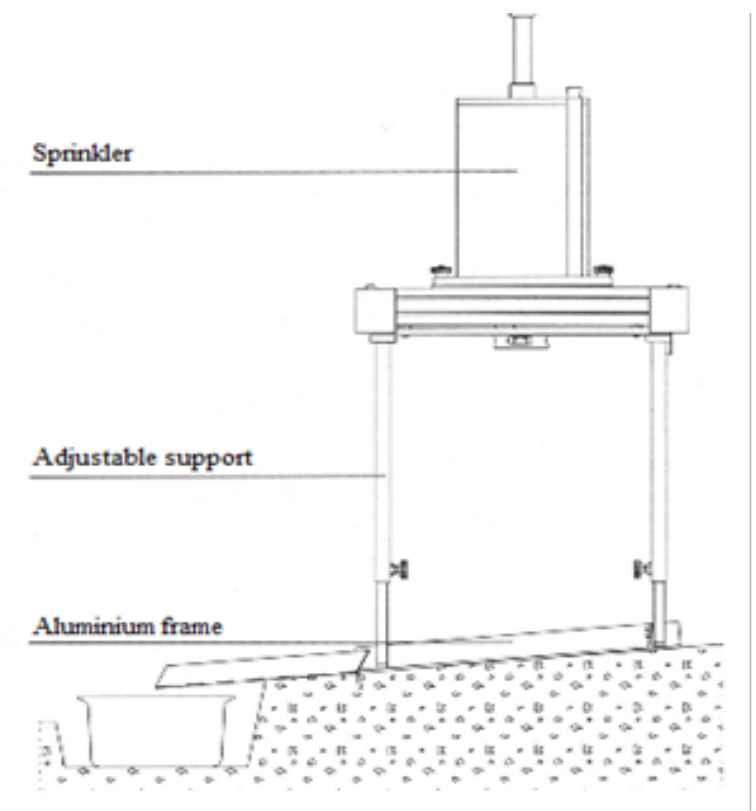

Figure 1. Rainfall simulator by Eijkelkamp 
Table 2. Influence of the soil additives application on the volume runoff coefficient

\begin{tabular}{|l|c|c|c|c|c|c|c|c|}
\hline & \multicolumn{9}{|c|}{$\varphi_{\mathrm{O}, \mathrm{p}}\left[\mathrm{L}^{3} \cdot \mathrm{L}^{-3}\right]$} & \multicolumn{2}{c|}{ Mean $\varphi_{\mathrm{O}, \mathrm{p}}\left[\mathrm{L}^{3} \cdot \mathrm{L}^{-3}\right]$} \\
\hline Improvement & 1. & 2. & 3. & 4. & 5. & 6. & 1.2 .3$. & 4.5 .6$. \\
\hline Control & 0.32 & 0.13 & 0.11 & 0.37 & 0.47 & 0.23 & 0.19 & 0.36 \\
\hline Perlite & 0.20 & 0.39 & 0.51 & 0.65 & 0.60 & 0.59 & 0.37 & 0.61 \\
\hline Charcoal & 0.41 & 0.40 & 0.39 & 0.55 & 0.55 & 0.54 & 0.4 & 0.55 \\
\hline Water glass & 0.45 & 0.34 & 0.37 & 0.02 & 0.26 & 0.16 & 0.4 & 0.15 \\
\hline
\end{tabular}

Notes: 1.2.3. Measurement series 1-application rates: perlite $150 \mathrm{~g}$, charcoal $1400 \mathrm{~g}$, water: water glass: $650: 1300 \mathrm{ml}$ 4. 5. 6. Measurement series $2-$ applied into the soil $+200 \mathrm{~g}$ of perlite. $+712 \mathrm{~g}$ of charcoal. $+1300: 2600 \mathrm{ml}-$ water : water glass

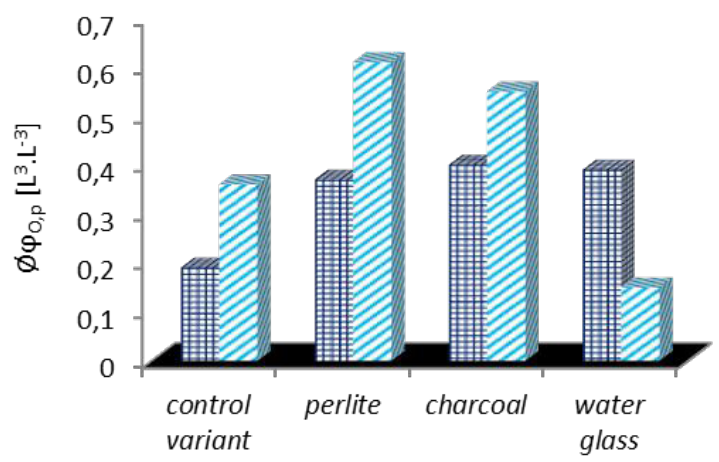

\#1.2. 3. series of measurements $\quad$ 4. 5. 6. series of measurements

Fig. 2. Changes of $\varphi_{\text {O.p }}$ depending on the soil additives

During the first part of the performed measurements, application of all soil additives resulted in doubled increase of volume runoff coefficient in comparison to control (Table 2, Fig. 2). Different values were obtained after another addition of soil additives (second set of measurements: series 4., 5., 6.). The volume runoff coefficient for control doubled, while perlite and charcoal resulted in lower increase. Surprisingly, the highest volume runoff coefficient was determined for perlite application (0.61) which resulted in $21.7 \mathrm{~mm}$ of surface runoff (Table 3, Fig. 3). Regarding the erosion control, the only positive effect was recorded for water glass application. Although the amount of surface runoff was in av- erage $7 \mathrm{~mm}$ higher than control during the first series of measurements, in the second series the amount dropped to $5 \mathrm{~mm}$ what was decrease by $41 \%$ in comparison to control.

Our hypothesis was correct only partially. The application of perlite and charcoal actually supported the process of surface runoff. The negative effect rose with the increasing application dosage.

\section{CONCLUSIONS}

During the first measurement series the amount of surface runoff increased for all treatments with soil additives by 30 up to $40 \%$ in comparison to control. In the second measure-

Table 3. Influence of the soil additives application on the surface runoff

\begin{tabular}{|l|c|c|c|c|c|c|c|c|}
\hline & \multicolumn{7}{|c|}{ Surface runoff $-\mathrm{H}_{\text {O.p }}[\mathrm{mm}]$} & ${\text { Mean } \mathrm{H}_{\text {O.p }}[\mathrm{mm}]}_{4.5 .6 .}$ \\
\hline Improvement & 1. & 2. & 3. & 4. & 5. & 6. & 1.2 .3$. & 4.5 .6 \\
\hline Control & 11.29 & 4.56 & 3.84 & 12.88 & 16.5 & 8.05 & 6.6 & 12.5 \\
\hline Perlite & 7.04 & 13.57 & 18.07 & 22.97 & 21.18 & 20.89 & 12.9 & 21.7 \\
\hline Charcoal & 14.56 & 14.08 & 13.81 & 19.49 & 19.43 & 19.15 & 14.2 & 19.4 \\
\hline Water glass & 15.68 & 12.16 & 13 & 0.65 & 9.07 & 5.74 & 13.6 & 5.2 \\
\hline
\end{tabular}

Notes: 1.2.3. Measurement series 1-application rates: perlite $150 \mathrm{~g}$, charcoal $1400 \mathrm{~g}$, water: water glass: $650: 1300 \mathrm{ml}$ 4. 5. 6. Measurement series 2 - applied into the soil $+200 \mathrm{~g}$ of perlite. $+712 \mathrm{~g}$ of charcoal. $+1300: 2600 \mathrm{ml}-$ water : water glass 


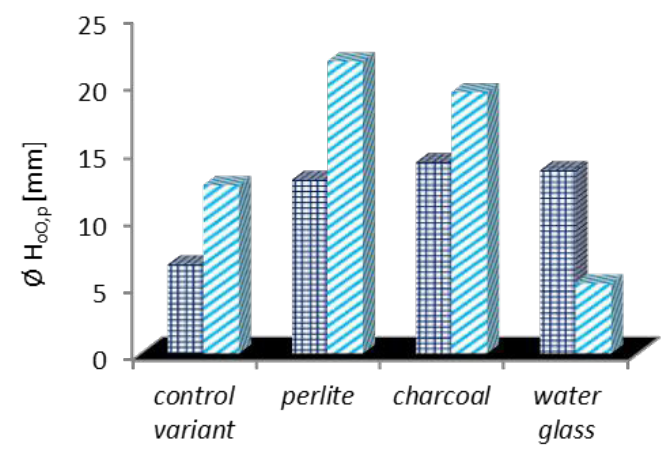

\#1. 2. 3. series of measurements

N 4. 5. 6. series of measurements

Fig. 3. Changes of $\mathrm{H}_{\text {O.p }}[\mathrm{mm}]$ in depending on the soil additives

ment series the highest surface runoff originated from the plot with the charcoal application, while in the third series it was from the plot with perlite application. At the same time, the surface runoff on this plot was the largest from all evaluated measurement series. Considering the results from these measurements, we can conclude that there was the absence of the positive impact of the soil additives application on surface runoff reduction.

Increased application dose of additives resulted in the positive effect in case of the water glass application. Surface runoff for this treatment decreased in average by about $41 \%$ in comparison to control. We can conclude that the application of perlite is not an adequate treatment for erosion control practices, since its application increased the surface runoff. According to the obtained results, it was found that the smallest surface runoff was recorded after the water glass application. This positive effect was observed only after the second application of the additives into the soil.

\section{Acknowledgements}

Work was supported by the grant VEGA 1/0268/14 ,Integrated protection of soil and water resources in the agricultural landscape“.

\section{REFERENCES}

1. Antal J., 2005. Protierózna ochrana pôdy. 1. vyd. Nitra SPU, pp. 79.

2. Antal J., 2010. Agrohydrológia. 5. nezmen. vyd. Nitra SPU, pp. 168.

3. Drgoňová K., 2014. Vplyv úprav povrchovej vrstvy pôdy na charakteristiky vodnej erózie pôdy: dizertačná práca. Nitra SPU, pp. 116.

4. Fulajtár E., Janský L., 2001. Vodná erózia pôdy a protierózna ochrana. 1. vyd. Výskumný ústav pôdoznalectva a ochrany pôdy. Bratislava, pp. 310 .

5. Holý M., Mls J., Váška J., 1982. Modelování erozních procesů. 1. vyd. Academia. Praha, pp. 84.

6. Janeček M., Pasák V., Tippl M., Pivcová J., Váška J., Toman F., 1999. Nové směry v protierozní ochraně půdy: studijní zpráva. Ústav zemědělských a potravinářských informací. Praha, pp. 55.

7. Janeček M., et al. 2008. Základy erodologie. Česká zemědělská univerzita. Praha, pp. 172.

8. Operating instructions. 2016. https://de.eijkelkamp. $\mathrm{com} /$ produkte/feldmessger-te/regensimulator-f-rerosionstests.html [2016-02-10].

9. Regensimulator für Erosionstests. 2016. https:// de.eijkelkamp.com/produkte/feldmessger-te/regensimulator-f-r-erosionstests.html [2016-02-10].

10. Toy J.T., Foster R.G., Renard G.K., 2002. Soil erosion: processes. prediction. measurement. and control. John Willey \& Sons Inc., New York, pp. 338. 